\title{
Pengaruh Religious Commitment Terhadap Penyesuaian Diri Mahasiswa
}

\author{
Halimatus Sakdiah, Rabiatul Adawiah, Muhammad Husaini Abbas ${ }^{1}$ \\ Universitas Islam Negeri (UIN) Antasari Banjarmasin
}

\begin{abstract}
The self-adjustment ability on campus is an important requirement of student education success. Therefore students should have good adjustment skills. This study aims to determine the adjustment ability and religious commitment of students in the campus IAIN Antasari, and to know the influence of religious commitment to student selfadjustment. The method used is quantitative method, with simple linear regression analysis. The research subjects were IAIN Antasari students in each faculty, and 236 students were selected as samples. The results showed that there was a significant positive religious commitment influence on the students' self adjustment at IAIN Antasari $(R=0.699(\rho=0.000))$. Each dimension of religious commitment also has a significant positive effect on students' self-adjustment. The influence of religious belief dimension $(R=0.484(\rho=0.000))$, religious practice dimension $(R$ $=0.596(\rho=0.000))$, religious knowledge dimension $(R=0.613=0.000))$, and religious effect dimension $(R=0.689$ $(\rho=0.000))$ on students' self-adjustment. It shows that the higher the religious commitment of the students, the better the students' self-adjustment. Therefore, the religious commitment of students is very important to be improved so that the students' self-adjustment will be better.
\end{abstract}

Keyword: Religious commitment; Self Adjusment; college student

\begin{abstract}
Abstrak
Kemampuan penyesuaian diri di kampus adalah persyaratan penting keberhasilan pendidikan mahasiswa. Oleh karena itu, mahasiswa harus memiliki keterampilan penyesuaian yang baik. Penelitian ini bertujuan untuk mengetahui kemampuan penyesuaian diri dan komitmen keagamaan mahasiswa di kampus IAIN Antasari, dan untuk mengetahui pengaruh komitmen agama terhadap penyesuaian diri mahasiswa. Metode yang digunakan adalah metode kuantitatif, dengan analisis regresi linier sederhana. Subjek penelitian adalah mahasiswa IAIN Antasari di masing-masing fakultas, dan 236 mahasiswa terpilih sebagai sampel. Hasil penelitian menunjukkan bahwa ada pengaruh komitmen religius positif yang signifikan terhadap penyesuaian diri mahasiswa di IAIN Antasari $(R=0,699(\rho=0,000))$. Setiap dimensi komitmen agama juga memiliki pengaruh positif yang signifikan terhadap penyesuaian diri siswa. Pengaruh dimensi keyakinan agama $(R=0,484(\rho=0,000))$, dimensi praktik keagamaan $(R=0,596(\rho=0,000))$, dimensi pengetahuan agama $(R=0,613=0,000))$, dan dimensi efek agama $(R=0,689(\rho=0,000))$ pada penyesuaian diri mahasiswa. Hal ini menunjukkan bahwa semakin tinggi komitmen religius mahasiswa, semakin baik penyesuaian diri mahasiswa. Oleh karena itu, komitmen agama mahasiswa sangat penting untuk ditingkatkan sehingga penyesuaian diri mahasiswa akan lebih baik.
\end{abstract}

${ }^{1}$ Korespondensi untuk tulisan ini ditujukan kepada email halima_sakdia@ymail.com 
Kata kunci: Komitemen keagamaan; penyesuaian diri; mahasiswa

\section{Pendahuluan}

Penyesuaian diri menurut Fatimah adalah proses bagaimana individu mencapai keseimbangan diri dalam memenuhi kebutuhan sesuai dengan lingkungan (Fatimah, 2006). Penyesuaian diri ini memiliki dua aspek yaitu penyesuaian pribadi dan penyesuaian sosial. Penyesuaian pribadi adalah kemampuan individu untuk menerima dirinya sendiri sehingga tercapai hubungan yang harmonis antara dirinya dengan lingkungan sekitarnya. Penyesuaian sosial adalah kemampuan seseorang untuk mematuhi aturan, hukum, adat, nilai dan norma yang berlaku dalam masyarakat (Fatimah, 2006).

Menurut Schneiders penyesuaian sosial merupakan kapasitas atau kemampuan yang dimiliki oleh setiap individu untuk dapat bereaksi secara efektif dan bermanfaat terhadap realitas, situasi dan relasi sosial, sehingga kriteria yang harus dipenuhi dalam kehidupan sosialnya dapat terpenuhi dengan cara yang dapat diterima dan memuaskan. Selanjutnya Schneiders membagi penyesuaian sosial tersebut ke dalam tiga setting yakni keluarga, sekolah dan masyarakat (Schneiders, 1960).

Pada dasarnya manusia selalu dituntut untuk mampu menyesuaikan diri dengan lingkungannya, termasuk lingkungan kampus. Setiap komponen civitas akademika diharapkan mampu menyesuaikan diri dengan kehidupan sosial kampus termasuk mahasiswa. Kemampuan menyesuaikan diri dengan lingkungan kampus ditunjukkan dengan berbagai perilaku yang sesuai dengan norma yang berlaku di kampus, diantaranya dapat mentaati berbagai peraturan perkuliahan, berakhlak mulia baik terhadap dosen dan mahasiswa lainnya, dengan kata lain setiap mahasiswa harus mampu menciptakan suatu relasi yang sehat dengan dosen, karyawan dan mahasiswa. Di samping itu mahasiswa juga dapat berperan aktif dalam berbagai kegiatan kampus terutama kegiatan pembelajaran, bertanggung jawab dengan tugastugas perkuliahan dan menghargai nilai-nilai yang berlaku dalam lingkungan kampusnya dan lain-lain.

Namun realitasnya tidak semua mahasiswa memiliki kemampuan penyesuaian diri yang baik di kampus. Beberapa perilaku mahasiswa yang menunjukkan ketidakmampuan penyesuaian diri di kampus diantaranya adalah adanya mahasiswa yang tidak mentaati 
peraturan kampus dan fakultasnya yaitu terlambat masuk kelas perkuliahan, tidak masuk kuliah tanpa pemberitahuan, berpakaian tidak sopan, menggunakan sandal di kelas, nitip absen kepada teman, bertutur kata yang kurang santun, peminjaman buku perpustakaan yang sering terlambat bahkan tidak dikembalikan sama sekali, menyontek ketika ujian, tidak mengerjakan tugas yang diberikan dosen, atau meminta orang lain mengerjakan tugas kuliahnya, dan lain-lain.

Perilaku mahasiswa tersebut menunjukkan adanya gejala penyesuaian diri yang buruk terhadap situasi, kondisi, aturan, dan upaya-upaya yang dilakukan perguruan tinggi. Padahal sebagai mahasiswa, mereka tentu dihadapkan pada berbagai norma yang berlaku di lingkungan kampus. Mahasiswa harus berjuang untuk menyesuaikan diri dengan lingkungan sosial kampusnya kalau ingin sukses dalam belajar, karena kemampuan penyesuaian diri di kampus akan menunjang keberhasilan dalam menyelesaikan studi di kampus. Keberhasilan mahasiswa menyelesaikan studi mahasiswa selalu ditunjukkan dengan perilaku yang baik atau sesuai dengan peraturan dan nilai yang berlaku di kampus. Sehingga kemampuan penyesuaian diri di kampus sangat penting dimiliki oleh setiap mahasiswa.

Schneiders (Schneiders, 1960) berpandangan bahwa adjusment (penyesuaian diri) merupakan rasa individu terhadap realitas yang dipersepsinya. Baik buruknya penyesuaian diri individu tersebut sangat tergantung bagaimana ia mempersepsi, menilai dan mengevaluasi realitas yang dihadapinya.

Mengapa ada mahasiswa yang tidak mampu menyesuaikan diri dengan baik di lingkungan kampus? Schneiders (Schneiders, 1960) mengemukakan bahwa salah satu faktor yang mempengaruhi penyesuaian diri adalah agama. Agama memberikan suasana psikologis yang akan mengurangi konflik, frustasi dan ketegangan sehingga suasana damai dan tenang dirasakan individu. Hal tersebut nampak pada kemampuan individu untuk memberikan respon yang matang, bermanfaat dan efisien dalam berhubungan dengan lingkungan sosialnya. Sehingga pada penelitian ini, peneliti mencoba melihat pengaruh agama (religious commitment) dengan kemampuan penyesuaian diri mahasiswa di kampus.

Glock(Glock, 1973), Glock dan Stark (Glock \& Stark, 1970) mengemukakan lima dimensi religious commitment, yaitu: 
1. Dimensi Religous belief/the religious ideological (dimensi keyakinan), dimensi keyakinan religius ini mencakup hal-hal apa yang diyakini sebagai bagian dari agama, seberapa kuat keyakinan ini dipegang dan seberapa penting kepercayaan ini dalam kehidupan orang tersebut. Dimensi ini berisi pengharapan-pengharapan di mana orang religius berpegang teguh pada pandangan teologis tertentu dan mengakui kebenaran doktrin-dokterin tersebut.

2. Dimensi Religious practise/the religous ritualistic (dimensi ibadah), berhubungan dengan seperangkat perilaku yang diharapkan akan muncul dari seseorang yang menyatakan diri menyakini suatu agama tertentu yaitu berupa perilaku-perilaku yang spesifik yang menjadi bagian dari agama tersebut. Tata cara praktik keagamaan bisa sangat bervariasi dengan lainnya, bergantung kepada bagaimana agama tersebut teroganisasikan dan terbagi-bagi. Semakin agama menjadi terstruktur dalam organisasi, maka semakin spesifik pula aturanaturan pelaksanaannya, cara berpakaiannya, maupun tingkatan otoritasnya.

3. Dimensi Religious feeling/the religious experiental (dimensi pengalaman agama), berkisar seputar wilayah mental emosional pada individu, kejadian-kejadian religius yang mungkin dikatakan sebagai sebuah "pengalaman religius", perasaan fisik, psikologis dan kesejahteraan spritual (spritual well being) sebagai buah dari keyakinan dan semacamnya. Keadaan perasaan (feeling) memiliki berbagai fungsi dalam kehidupan beragama. Salah satunya bersifat motivasional.

4. Dimensi Religious knowledgel the religious intellectual (dimensi pengetahuan agama), mencakup informasi yang dimiliki seseorang mengenai keyakinannya. Pengetahuan religius dapat memiliki derajat kepentingan yang berbeda-beda. Bisa saja seseorang memiliki komitmen terhadap suatu keyakinan tertentu memiliki skor yang tinggi, tapi dari aspek pengetahuannya sangat sedikit, atau sebaliknya.

5. Dimensi Religious effect/the religious consequential (dimensi konsekuensi agama), mencakup efek suatu agama pada kehidupan seseorang. Dimensi ini mengacu pada identifikasi akibatakibat keyakinan keagamaan, praktik, pengalaman dan pengetahuan seseorang dari hari ke hari.

Dimensi-dimensi dari religious commitment tersebut oleh Gordon F. De Jong, Joseph E. Faulkner dan Rex H. Warland dinamakan dengan generic religiousity (Jong, Faulkner, \& 
Warland, 1976). Merujuk pada konsep yang dikemukakan oleh Glocks dan Stark tentang religious commitment pula, Riaz Hasan mengembangkan konsep tentang kesalehan muslim. Lima dimensi yang menunjukkan ekspresi dan signifikansi kesalehan muslim adalah the ideological, the ritualistic, the devotional, the experiental dan the consequential religious (Hassan, 2005).

Dalam penelitian ini penyesuaian diri mahasiswa dibatasi pada lingkungan kampus. Penyesuaian diri (adjusment) di kampus adalah sejauhmana kemampuan mahasiswa dalam bereaksi secara efektif dan bermanfaat terhadap realitas, situasi dan dalam menjalin relasi di lingkungan kampus, dan sejauhmana mahasiswa mau menerima dan menghormati otoritas kampus, mampu menjalin relasi dengan teman dan dosen, mau menerima tanggung jawab sebagai mahasiswa dan sebagai bagian dari institusi, serta mau berpartisipasi dengan kegiatan kampus. Mengacu pada teori Schneider, peneliti membatasi aspek penyesuaian diri di kampus menjadi tiga aspek, yatu:

1. Aspek emosi; yaitu kemampuan mahasiswa untuk mengatasi gejolak perasaan yang terjadi yang ditimbulkan oleh lingkungan kampusnya. Unsur-unsurnya meliputi; mampu mengimbangi rasa kesedihan, mampu mengatasi rasa cemas, mampu mengatasi perasaan ketergantungan, mampu menghilangkan perasaan iri hati, dan mampu menyiasati perasaan marah.

2. Aspek sosiabilitas; yaitu kemampuan mahasiswa untuk menampilkan perilaku yang sesuai dengan norma dan berhubungan dengan orang lain di kampus. Unsur-unsurnya meliputi; mampu menjalin keakraban, mampu bersifat ramah, mampu bekerja sama, mampu bergaul dengan baik, dan memperhatikan kepentingan/ kebutuhan orang lain.

3. Aspek objektivitas; yaitu kemampuan mahasiswa untuk bersikap objektif dan berinteraksi dengan lingkungan kampus. Unsur-unsurnya; mampu bertindak objektif, mampu bertindak realistis, mampu berpikir kritis, mampu mentaati aturan kampus.

Berdasarkan permasalahan yang telah diuraikan tersebut, peneliti menentukan rumusan masalah adalah: 1) Apakah ada pengaruh religious commitment terhadap penyesuaian diri mahasiswa di kampus IAIN Antasari Banjarmasin? 2) Dimensi mana saja dari religious 
commitment yang paling berpengaruh pada masing-masing aspek penyesuaian diri mahasiswa di kampus IAIN Antasari Banjarmasin?

\section{Metode}

Penelitian ini termasuk penelitian ex post facto, yaitu suatu pendekatan yang memungkinkan peneliti untuk mengumpulkan data secara statistik dan sebagaimana adanya terhadap hal-hal yang telah terjadi tanpa memberikan perlakukan atau manipulasi terhadap variabel penelitian. Data yang dihimpun hanya berdasarkan apa yang telah berlangsung sebelumnya yaitu data tentang religious commitment dan penyesuaian diri mahasiswa di kampus. Pendekatan yang dipakai adalah explanatory survey. Penelitian survey mengkaji populasi (universe) yang besar maupun kecil dengan menyeleksi serta mengkaji sampel yang dipilih dari populasi itu, untuk menemukan insidensi, distribusi dan interalasi relative dari variabel-variabel (Kerlinger, 2004). Eksplanasi dilakukan dengan menggunakan metode kuantitatif yang bersifat deskriptif dan verifikatif.

Objek penelitian ini adalah religious commitment dan penyesuaian diri mahasiswa. Populasi dalam penelitian ini adalah semua mahasiswa IAIN Antasari. Jumlah sampel yang terpilih sebesar 236 orang (yang terdiri 113 mahasiswa Fakultas Tarbiyah dan Keguruan, Fakultas mahasiswa Fakultas Syariah dan Ekonomi Islam, 37 mahasiswa Fakultas Dakwah dan Komunikasi, dan 35 mahasiswa Fakultas Ushuluddin dan Humaniora) dengan menggunakan teknik simple random sampling.

Instrumen atau alat ukur yang digunakan berupa kuesioner tentang religious commitment dan penyesuaian diri. Kuesioner disusun oleh peneliti berdasarkan konsep Religious commitment dari Glock dan Starck (1965) dan Adjusment dari Schneiders (1960) dalam bentuk skala Summated Rating. Prosedur penyusunannya bertolak dari konstruksi teoritis yang dikristalisasikan dalam konsep operasionalisasi variabel yang memuat indikator-indikatornya. Setelah alat ukur dikonstruksi, terlebih dahulu dilakukan uji coba (try out) untuk mengetahui ketepatan/kesahihan (validity) dan keterandalan/konsistensi (reliability) alat ukur penelitian dengan menggunakan Cronbach alpha. Data yang terkumpul selanjutnya diuji dengan menggunakan statistik parametrik, melalui regresi linear sederhana. 


\section{Hasil}

Gambaran tentang Religious commitment terhadap 236 responden penelitian, dapat dilihat dalam tabel berikut.

Tabel 1.

Religious commitment Mahasiswa

\begin{tabular}{crrr}
\hline No & Kategorisasi & Frekuensi & Persentasi \\
\hline 1 & Sangat Tinggi & 160 & 67.80 \\
2 & Tinggi & 68 & 28.81 \\
3 & Sedang & 6 & 2.54 \\
4 & Rendah & 1 & 0.42 \\
5 & Sangat Rendah & 1 & 0.42 \\
6 & No Comitment & 0 & 0 \\
\hline \multicolumn{4}{r}{} \\
\hline
\end{tabular}

Tabel tersebut menunjukkan bahwa religious commitment mahasiswa lebih banyak berada pada kategori sangat tinggi, yakni sebanyak $67.80 \%$. Selanjutnya $28.81 \%$ religious commitment mahasiswa berada pada kategori tinggi, dan 2.52\% pada kategori sedang. Disamping itu ditemukan pula mahasiswa dengan religious commitment yang rendah bahkan rendah sekali, masing-masing berjumlah $0.42 \%$. Dengan demikian kadar keterikatan religius terhadap agama Islam yang dianut oleh mahasiswa lebih banyak berada pada kategori sangat baik.

Adapun gambaran dimensi religious commitment mahasiswa dapat dilihat dari tabel berikut:

Tabel 2.

Dimensi Religious commitment Mahasiswa

\begin{tabular}{|c|c|c|c|c|c|c|c|c|c|c|c|}
\hline \multirow[t]{2}{*}{$\begin{array}{c}\mathrm{N} \\
\mathrm{o}\end{array}$} & \multirow[t]{2}{*}{ Kategorisasi } & \multicolumn{2}{|c|}{$\begin{array}{c}\text { Religious } \\
\text { belief }\end{array}$} & \multicolumn{2}{|c|}{$\begin{array}{c}\text { Religious } \\
\text { Ritual }\end{array}$} & \multicolumn{2}{|c|}{$\begin{array}{c}\text { Religious } \\
\text { feeling }\end{array}$} & \multicolumn{2}{|c|}{$\begin{array}{c}\text { Religious } \\
\text { knowledge }\end{array}$} & \multicolumn{2}{|c|}{$\begin{array}{c}\text { Religious } \\
\text { Effect }\end{array}$} \\
\hline & & $\mathrm{F}$ & $\%$ & $\mathrm{~F}$ & $\%$ & $\mathrm{~F}$ & $\%$ & $\mathrm{~F}$ & $\%$ & $\bar{F}$ & $\%$ \\
\hline 1 & Sangat Tinggi & 220 & 93.2 & 41 & 17.4 & 169 & 71.6 & 121 & 51.3 & 126 & 53.4 \\
\hline 2 & Tinggi & 14 & 5.93 & 145 & 61.4 & 57 & 24.2 & 94 & 39.8 & 92 & 39 \\
\hline 3 & Sedang & 1 & 0.42 & 44 & 18.6 & 8 & 3.39 & 15 & 6.36 & 14 & 5.93 \\
\hline 4 & Rendah & 0 & 0 & 4 & 1.69 & 1 & 0.42 & 5 & 2.12 & 3 & 1.27 \\
\hline 5 & Sangat Rendah & 1 & 0.42 & 2 & 0.85 & 1 & 0.42 & 1 & 0.42 & 1 & 0.42 \\
\hline 6 & No Comitment & 0 & 0 & 0 & 0 & 0 & 0 & 0 & 0 & 0 & 0 \\
\hline & Total & 236 & 100 & 236 & 100 & 236 & 100 & 236 & 100 & 236 & 100 \\
\hline
\end{tabular}

Tabel 2 menunjukkan bahwa mahasiswa memiliki religious belief yang sangat baik, dimana 93.2 persen mahasiswa berada pada kategori sangat tinggi. Nilai tersebut mendominasi dari semua dimensi (religious feeling, knowledge dan effect) juga berada pada kategori sangat tinggi. 
Sedangkan pada dimensi religious practice/ritual kebanyakan mahasiswa hanya berada pada kategori tinggi (61,4 persen). Adapun kategori sangat rendah paling banyak ditemukan pada dimensi religious ritualistic (0.85 persen). Ini berarti untuk dimensi ritualistic ini ditemukan adanya mahasiswa yang kurang mengamalkan ajaran agama dan kurang mentaati ajaran agama Islam.

Selanjutnya gambaran religious commitment mahasiswa berdasarkan Fakultas di IAIN Antasari sebagai berikut.

Tabel 3.

Gambaran Religious commitment Mahasiswa Masing-Masing Fakultas

\begin{tabular}{|c|c|c|c|c|c|c|c|c|c|}
\hline \multirow[t]{2}{*}{ No } & \multirow[t]{2}{*}{ Kategorisasi } & \multicolumn{2}{|c|}{$\begin{array}{l}\text { Fakultas } \\
\text { Tarbiyah }\end{array}$} & \multicolumn{2}{|c|}{$\begin{array}{c}\text { Fakultas } \\
\text { Syariah }\end{array}$} & \multicolumn{2}{|c|}{$\begin{array}{l}\text { Fakultas } \\
\text { Dakwah }\end{array}$} & \multicolumn{2}{|c|}{$\begin{array}{c}\text { Fakultas } \\
\text { Ushuluddin }\end{array}$} \\
\hline & & $\mathrm{F}$ & $\%$ & $\mathrm{~F}$ & $\%$ & $\mathrm{~F}$ & $\%$ & $\mathrm{~F}$ & $\%$ \\
\hline 1 & Sangat Tinggi & 74 & 65.5 & 34 & 66.67 & 26 & 70.27 & 26 & 74.29 \\
\hline 2 & Tinggi & 32 & 28.3 & 17 & 33.33 & 11 & 29.73 & 9 & 25.71 \\
\hline 3 & Sedang & 5 & 4.42 & 0 & 0 & 0 & 0 & 0 & 0 \\
\hline 4 & Rendah & 1 & 0.88 & 0 & 0 & 0 & 0 & 0 & 0 \\
\hline 5 & Sangat Rendah & 1 & 0.88 & 0 & 0 & 0 & 0 & 0 & 0 \\
\hline 6 & No Comitment & 0 & 0 & 0 & 0 & 0 & 0 & 0 & 0 \\
\hline & Total & 113 & 100 & 51 & 100 & 37 & 100 & 35 & 100 \\
\hline
\end{tabular}

Tabel 3 menggambarkan bahwa mahasiswa yang memiliki religious commitment berada pada kategori sangat tinggi lebih banyak terdapat pada Fakultas Ushuluddin yakni 74.29 persen. Bahkan pada mahasiswa Fakultas Ushuluddin, Syariah, dan Dakwah tidak ditemukan mahasiswa yang memiliki religious commitment sedang maupun rendah. Religious commitment mahasiswa dengan kategori rendah dan sangat rendah ditemukan hanya pada Fakultas Tarbiyah (0.88 persen).

Adapun kemampuan penyesuaian diri mahasiswa terhadap lingkungan kampus dapat digambarkan sebagai berikut.

Tabel 4.

Gambaran Penyesuaian Diri Mahasiswa IAIN Antasari

\begin{tabular}{llll}
\hline No & Kategorisasi & Frekuensi & Persentasi \\
\hline
\end{tabular}




\begin{tabular}{rrrr}
\hline 1 & Sangat Baik & 73 & 30.93 \\
2 & Baik & 127 & 53.81 \\
3 & Sedang & 35 & 14.83 \\
4 & Kurang Baik & 1 & 0.42 \\
5 & Buruk & 0 & 0 \\
6 & Sangat Buruk & 0 & 0 \\
\hline \multicolumn{4}{r}{ Total } \\
\hline
\end{tabular}

Tabel 4 menggambarkan bahwa 30,93 persen kemampuan penyesuaian diri mahasiswa di kampus IAIN Antasari berada pada kategori sangat baik. Kebanyakan mahasiswa ditemukan memiliki kemampuan penyesuaian diri dengan kategori baik yakni 53.81 persen, dan selebihnya 14.83 persen mahasiswa masih pada kategori sedang. Adapun mahasiswa yang kurang baik penyesuaian diri di kampus IAIN Antasari hanya sebanyak 0.42 persen. Dengan demikian umumnya mahasiswa IAIN Antasari memiliki kemampuan penyesuaian diri yang baik.

Adapun kemampuan penyesuaian diri mahasiswa pada tiap Fakultas dapat dilihat pada tabel berikut.

Tabel 5.

Kemampuan Penyesuaian Diri Mahasiswa Masing-masing Fakultas

\begin{tabular}{|c|c|c|c|c|c|c|c|c|c|}
\hline \multirow[t]{2}{*}{ No } & \multirow[t]{2}{*}{ Kategorisasi } & \multicolumn{2}{|c|}{$\begin{array}{l}\text { Fakultas } \\
\text { Tarbiyah }\end{array}$} & \multicolumn{2}{|c|}{$\begin{array}{c}\text { Fakultas } \\
\text { Syariah }\end{array}$} & \multicolumn{2}{|c|}{$\begin{array}{l}\text { Fakultas } \\
\text { Dakwah }\end{array}$} & \multicolumn{2}{|c|}{$\begin{array}{l}\text { Fakultas } \\
\text { Ushuluddin }\end{array}$} \\
\hline & & $\mathrm{F}$ & $\%$ & $\mathrm{~F}$ & $\%$ & $\mathrm{~F}$ & $\%$ & $\mathrm{~F}$ & $\%$ \\
\hline 1 & Sangat Baik & 33 & 29.2 & 14 & 27.45 & 15 & 40.54 & 10 & 28.57 \\
\hline 2 & Baik & 60 & 53.1 & 29 & 56.86 & 17 & 45.95 & 23 & 65.71 \\
\hline 3 & Sedang & 19 & 16.8 & 8 & 15.69 & 5 & 13.51 & 2 & 5.71 \\
\hline 4 & Kurang Baik & 1 & 0.8 & 0 & 0 & 0 & 0 & 0 & 0 \\
\hline 5 & Buruk & 0 & 0 & 0 & 0 & 0 & 0 & 0 & 0 \\
\hline 6 & Sangat Buruk & 0 & 0 & 0 & 0 & 0 & 0 & 0 & 0 \\
\hline & Total & 113 & 100 & 51 & 100 & 37 & 100 & 35 & 100 \\
\hline
\end{tabular}

Kemampuan penyesuaian diri pada tabel 5 menunjukkan bahwa kategori sangat baik lebih banyak terdapat pada Fakultas Dakwah (40,54 persen), sedangkan kemampuan penyesuaian diri dengan kategori baik lebih banyak terdapat pada Fakultas Ushuluddin. Adapun kemampuan penyesuaian diri dengan kategori sedang lebih banyak terdapat pada Fakultas Tarbiyah (16.8 persen), demikian juga ketegori kurang baik ditemukan pada Fakultas Tarbiyah 
(0.8 persen). Secara umum kemampuan penyesuaian diri mahasiswa pada tiap-tiap Fakultas berada pada kategori baik.

Gambaran kemampuan penyesuaian diri mahasiwa jika dilihat pada aspek emosi, aspek sosiabilitas dan aspek objektivitas dapat dilihat pada tabel berikut.

Tabel 6.

Aspek Penyesuaian Diri Mahasiswa

\begin{tabular}{|c|c|c|c|c|c|c|c|}
\hline $\begin{array}{l}\mathrm{N} \\
\mathrm{o}\end{array}$ & \multirow[t]{2}{*}{ Kategorisasi } & \multicolumn{2}{|c|}{$\begin{array}{l}\text { Aspek } \\
\text { Emosi }\end{array}$} & \multicolumn{2}{|c|}{$\begin{array}{c}\text { Aspek } \\
\text { Sosiabilitas } \\
\end{array}$} & \multicolumn{2}{|c|}{$\begin{array}{c}\text { Aspek } \\
\text { Objektivitas } \\
\end{array}$} \\
\hline & & $\mathrm{F}$ & $\%$ & $\mathrm{~F}$ & $\%$ & $\mathrm{~F}$ & $\%$ \\
\hline 1 & Sangat Baik & 88 & 37.29 & 40 & 16.95 & 73 & 30.93 \\
\hline 2 & Baik & 111 & 47.03 & 131 & 55.51 & 114 & 48.31 \\
\hline 3 & Sedang & 33 & 13.98 & 50 & 21.19 & 46 & 19.49 \\
\hline 4 & Kurang Baik & 3 & 1.27 & 15 & 6.35 & 3 & 1.27 \\
\hline 5 & Buruk & 1 & 0.42 & 0 & 0 & 0 & 0 \\
\hline 6 & Sangat Buruk & 0 & 0 & 0 & 0 & 0 & 0 \\
\hline & Total & 236 & 100 & 236 & 100 & 236 & 100 \\
\hline
\end{tabular}

Tabel 6 menunjukkan bahwa kemampuan penyesuaian diri mahasiwa yang berada pada kategori sangat tinggi lebih banyak terdapat pada aspek emosi (37,29 persen). Sedangkan kemampuan penyesuaian diri mahasiswa pada kategori baik lebih banyak terdapat pada aspek sosiabilitas (55,51 persen). Demikian juga kemampuan penyesuaian diri mahasiswa yang berada pada kategori sedang dan kurang baik lebih banyak terdapat pada aspek sosiabilitas (21,19 persen dan 6.35 persen). Adapun kemampuan penyesuaian diri dengan kategori buruk hanya ditemukan pada aspek emosi (0.42 persen). Secara umum kemampuan penyesuaian diri mahasiwa jika dilihat dari ketiga aspek tersebut (emosi, sosiabilitas dan objektivitas) berada pada kategori baik.

Adapun hasil pengujian hipotesis pengaruh religious commitment dengan penyesuaian diri mahasiswa dapat dilihat pada tabel berikut:

Tabel 7.

Hasil Pengujian Hipotesis

\begin{tabular}{crrrrrrr}
\hline Variabel & $\mathrm{R}$ & $R$ Square & thitung & Fhitung & Sig. & $\begin{array}{l}\text { Hipotesis } \\
\text { Penelitian }\end{array}$ & Ket. \\
\hline $\mathrm{X} \longrightarrow \mathrm{Y}$ & 0.699 & 0.489 & 14.963 & 223.895 & 0.000 & Diterima & Signifikan \\
\hline
\end{tabular}

Sumber: Hasil analisis data dengan taraf signifikansi sebesar $\alpha=0,05$ (sig.(1-tailed)). 
Nilai Regresi adalah 0.699. Nilai 0.699 adalah R hitung. Angka tersebut menunjukkan pengaruh yang kuat religious commitment terhadap penyesuaian diri mahasiswa di kampus IAIN Antasari. Hubungan bersifat positif correlation, artinya peningkatan pada religious commitment akan meningkatkan kemampuan penyesuaian diri mahasiswa di kampus. Nilai probabilitas $0.000<$ taraf signifikansi 0.05 , menunjukkan korelasi yang signifikan.

Nilai $R$ Square $\left(R^{2}\right)$ sebesar 0.489 , artinya variasi yang terjadi terhadap kemampuan penyesuaian diri mahasiswa sebesar 48.9 persen disebabkan atau dipengaruhi oleh variasi religious commitment yang dimiliki mahasiswa, dan sisanya sebesar 51.1 persen dipengaruhi oleh faktor-faktor lain diluar penelitian ini.

Berdasarkan uji Anova atau F test, didapat F hitung adalah 223.895 dengan signifikansi 0.000. Karena F hitung > dari F tabel $(223.895$ > 3.69), maka Ho ditolak, artinya ada pengaruh secara signifikan antara religious commitment terhadap penyesuaian diri. Dari nilai probabilitas (0.000) juga terlihat jauh lebih kecil dari 0.05, maka model regresi ini dapat dipakai untuk memprediksi penyesuaian diri, atau dengan kata lain, religious commitment mempengaruhi penyesuaian diri mahasiswa di kampus.

Konstanta sebesar 20.230 menyatakan bahwa jika tidak ada religious commitment yang dimiliki mahasiswa, maka penyesuaian diri mahasiswa berada pada kategori 20.230 atau sangat rendah. Koefisien regresi $X$ sebesar 0.669 menyatakan bahwa setiap kenaikan (karena tanda + ) satu kemampuan religious commitment akan meningkatkan sebesar 0.669 penyesuaian diri mahasiswa.

Uji $\mathrm{t}$ berguna untuk menguji signifikansi koefisien regresi (b), apakah variabel religious commitment $(\mathrm{X})$ berpengaruh secara nyata atau tidak terhadap variabel penyesuaian diri $(\mathrm{Y})$. Nilai t hitung dalam tabel Coefficients adalah 14.963. Sedangkan nilai t tabel tingkat signifikansi 1/2 0.05;236-2 adalah 1.960. Karena $\mathrm{t}$ hitung $>\mathrm{t}$ tabel maka Ho ditolak dan $\mathrm{H}_{1}$ diterima. Artinya terbukti bahwa religious commitment berpengaruh secara nyata (signifikan terhadap penyesuaian diri mahasiswa di kampus IAIN Antasari.

Sedangkan hasil pengujian regresi untuk pengaruh masing-masing dimensi religious commitment terhadap penyesuaian diri mahasiswa dapat digambarkan sebagai berikut:

Tabel 8. 


\section{Hasil Pengujian Regresi Tiap Demensi Religious Commitment}

\begin{tabular}{lcccc}
\hline $\begin{array}{c}\text { Dimensi Religious } \\
\text { commitment }\end{array}$ & $\begin{array}{c}\text { Nilai Koefisien } \\
\text { Regresi }\end{array}$ & t hitung & Sig & keterangan \\
\hline R. Belief & 0.484 & 8.463 & 0.00 & Ho ditolak \\
R. Practise & 0.596 & 11.350 & 0.00 & Ho ditolak \\
R. Feeling & 0.667 & 13.704 & 0.00 & Ho ditolak \\
R. Knowledge & 0.613 & 11.855 & 0.00 & Ho ditolak \\
R. Effect & 0.689 & 14.531 & 0.00 & Ho ditolak \\
\hline
\end{tabular}

Nilai koefisien regresi religious belief adalah 0.484. Angka tersebut menunjukkan terjadi korelasi yang moderat antara religious belief dengan penyesuaian diri mahasiswa di kampus IAIN Antasari. Angka yang positif menunjukkan adanya hubungan bersifat positif correlation, artinya peningkatan pada religious belief akan meningkatkan kemampuan penyesuaian diri mahasiswa di kampus. Nilai probabilitas $0.00<$ taraf signifikansi 0.050, berarti menunjukkan korelasi/hubungan yang signifikan. Nilai t hitung adalah 8.463. Sedangkan nilai $\mathrm{t}$ tabel tingkat signifikansi $1 / 2$ 0.05;236-2 adalah 1.960. Karena t hitung $>\mathrm{t}$ tabel maka Ho ditolak dan $\mathrm{H}_{1}$ diterima. Artinya terbukti bahwa religious belief berpengaruh secara nyata (signifikan terhadap penyesuaian diri mahasiswa di kampus IAIN Antasari.

Nilai koefisien regresi religious practise adalah 0.596. Angka tersebut menunjukkan terjadi korelasi yang moderat antara religious practise/ritual dengan penyesuaian diri mahasiswa di kampus. Angka yang positif menunjukkan adanya hubungan bersifat positif correlation, artinya peningkatan pada religious belief akan meningkatkan kemampuan penyesuaian diri mahasiswa di kampus. Nilai probabilitas adalah 0.00 maka korelasi dikatakan signifikan. Nilai t hitung adalah 11.350. Sedangkan nilai $t$ tabel adalah 1.960. Karena $t$ hitung $>t$ tabel maka Ho ditolak dan $\mathrm{H}_{1}$ diterima. Artinya terbukti bahwa religious practice/ritual berpengaruh secara nyata (signifikan terhadap penyesuaian diri mahasiswa di kampus.

Nilai koefisien regresi religious feeling adalah 0.667. Angka tersebut menunjukkan terjadi korelasi yang kuat antara religious feeling dengan penyesuaian diri mahasiswa di kampus. Nilai probabilitas adalah $0.00<$ taraf signifikansi 0.05 , berarti menunjukkan korelasi/hubungan yang signifikan. Nilai t hitung adalah $13.704>$ t tabel 1.960 artinya terbukti bahwa religious feeling berpengaruh secara nyata (signifikan terhadap penyesuaian diri mahasiswa. 
Nilai koefisien regresi religious knowledge adalah 0.613 menunjukkan adanya korelasi kuat antara religious knowledge dengan penyesuaian diri mahasiswa. Nilai probabilitas adalah $0.000<$ 0.050 menunjukkan korelasi/hubungan yang signifikan. Nilai $\mathrm{t}$ hitung adalah $11.855>\mathrm{t}$ tabel 1.960. terbukti bahwa religious knowledge berpengaruh secara nyata (signifikan terhadap penyesuaian diri mahasiswa di kampus IAIN Antasari.

Nilai koefisien regresi religious effect adalah 0.689. Angka tersebut menunjukkan terjadi korelasi yang kuat antara religious effect dengan penyesuaian diri mahasiswa. Angka yang positif menunjukkan adanya hubungan bersifat positif correlation, artinya peningkatan pada religious effect akan meningkatkan kemampuan penyesuaian diri mahasiswa di kampus. Nilai probabilitas adalah $0.00<0.05$, menunjukkan hubungan yang signifikan. Nilai t hitung adalah 14.531 > 1.960 maka religious knowledge berpengaruh secara nyata (signifikan) terhadap penyesuaian diri mahasiswa.

\section{Pembahasan}

Hasil pengujian hipotesis memperlihatkan bahwa masing-masing pasangan variabel terbukti mempunyai pengaruh positif yang signifikan. Nilai regresi pengaruh religious commitment dengan penyesuaian diri mahasiswa di kampus IAIN Antasari Banjarmasin sebesar $\mathrm{r}=0.699$ menunjukkan adanya pengaruh positif yang kuat antara religious commitment dengan penyesuaian diri mahasiswa. Ini berarti bahwa semakin tinggi atau meningkat religious commitment yang dimiliki mahasiswa, maka semakin tinggi atau meningkat kemampuan penyesuaian diri mahasiswa.

Hasil empirik dari penelitian ini menunjukkan bahwa mahasiswa IAIN Antasari Banjarmasin (67.80 persen) memiliki religious commitment sangat tinggi. Ini berarti 67.80 persen mahasiswa memiliki kadar keterikatan religius yang dimiliki mahasiswa terhadap agama sangat baik. Mahasiswa menyakini agama yang dianutnya dengan baik, melaksanaan ajaran agama, merasakan pentingnya agama, memiliki pengetahuan yang baik tentang agama yang diyakininya dan merasakan dampak dari agama yang diyakini dalam kehidupannya.

Religious commitment ini baik dan perlu dikembangkan pada diri mahasiswa karena dapat meningkatkan kemampuan penyesuaian diri mahasiswa di kampus IAIN Antasari 
Banjarmasin. Schneiders (Schneiders, 1960) mengungkapkan bahwa agama merupakan salah satu faktor yang mempengaruhi kemampuan penyesuaian diri seseorang terhadap lingkungannya, termasuk dalam hal ini lingkungan kampus.

Lebih lanjut Hendriati Agustiani mengemukakan bahwa penyesuaian diri yang dilakukan individu dapat dipengaruhi oleh: a) faktor kondisi fisik yang meliputi faktor keturunan, kesehatan, bentuk tubuh dan hal-hal lain yang berkaitan dengan fisik; b) faktor perkembangan dan kematangan, yang meliputi perkembangan intelektual, sosial, moral, dan kematangan emosional; c) faktor psikologis, yaitu faktor-faktor pengalaman individu, frutrasi dan konflik yang dialami, dan kondisi-kondisi psikologis seseorang dalam penyesuaian diri; d) faktor lingkungan, yaitu kondisi yang ada pada lingkungan, seperti kondisi keluarga, kondisi rumah, dan sebagainya; e) faktor budaya, termasuk adat istiadat dan agama yang turut mempengaruhi penyesuaian diri (Agustiani, 2006).

Secara umum pengaruh religious commitment dengan kemampuan penyesuaian diri mahasiswa di kampus terlihat bahwa agama turut memberikan peranan untuk menentukan kemampuan mahasiswa dalam melakukan penyesuaian diri di lingkungan kampusnya. Dengan demikian agama merupakan determinan penting terhadap kemahiran seseorang dalam menyesuaikan diri dengan lingkungan. Religious commitment berperan dalam membentuk penyesuaian diri yang baik pada mahasiswa.

Tingkah laku penyesuaian diri tersebut meliputi aspek emosi yaitu kemampuan seseorang untuk mengatasi gejolak perasaan yang terjadi yang ditimbulkan oleh lingkungannya. Aspek sosiabilitas yaitu kemampuan seseorang untuk menampilkan perilaku yang sesuai dengan norma di lingkungannya. Aspek objektivitas yaitu kemampuan seseorang untuk bersikap objektif dan berinteraksi dengan lingkungannya.

Selanjutnya hasil uji determinasi (konstribusi efektif) antara variabel religious commitment dengan penyesuaian diri mahasiswa di kampus adalah 49 persen. Artinya perkembangan tingkah laku penyesuaian diri mahasiswa di kampus IAIN Antasari 49 persen ditentukan oleh religious commitment yang dimiliki mahasiswa terhadap agama yang diyakininya. Selebihnya, sebesar 51 persen perkembangan kemampuan penyesuaian diri mahasiswa di kampus ditentukan oleh faktor-faktor lain, yang secara konseptual dikemukakan oleh Schneiders 
dipengaruhi oleh beberapa faktor, yaitu: 1) Kondisi jasmaniah yang meliputi, a) pengaruh hereditas (sifat bawaan) dan struktur jasmaniah, b) kesehatan dan penyakit jasmaniah, c) sistem syaraf, kenjar otot dan sebagainya; 2) Perkembangan dan kematangan dalam arti bahwa pencapaian penyesuaian diri banyak tergantung pada tingkat perkembangan dan kematangan. Tingkat perkembangan dan kematangan yang dicapai individu berbeda-beda; 3) Penentu psikologis yang meliputi, a) pengalaman, b) belajar, c) pendidikan, d) diterminasi diri, e) suasana psikologis; 4) Faktor lingkungan yang meliputi, a) lingkungan rumah dan keluarga, b) hubungan orang tua dan anak, c) hubungan saudara, d) lingkungan masyarakat, d) lingkungan sekolah dan kampus; 5) Kebudayaan (Schneiders, 1960).

Pendapat tersebut diperkuat oleh Hariyadi (Hariyadi, 1995) yang mengatakan bahwa pada dasarnya penyesuaian diri dipengaruhi oleh faktor internal dan eksternal yaitu: 1) Faktor-faktor internal meliputi; a) Faktor motif yaitu motif-motif sosial seperti motif berafiliasi, motif berprestasi dan motif mendominasi; b) Faktor harga diri remaja yaitu bagaimana remaja itu memandang tahapan dirinya sendiri, baik pada aspek fisik, psikologis, sosial maupun aspek akademik. Remaja dengan harga diri tinggi akan lebih memiliki kemampuan untuk melakukan penyesuaian yang menyenangkan dibandingkan remaja dengan harga diri rendah, pesimis ataupun kurang yakin terhadap dirinya sendiri; c) Faktor persepsi remaja yaitu pengamatan dan penilaian remaja terhadap objek peristiwa dan kehidupan, baik melalui proses kognisi maupun afeksi untuk membentuk konsep tentang objek tersebut; d) Faktor sikap remaja yaitu kecenderungan remaja untuk berperilaku positif atau negatif. Remaja yang bersikap positif terhadap sesuatu yang dihadapi akan lebih memiliki peluang untuk melakukan penyesuaian diri daripada remaja yang sering bersikap negatif atau suka menyangkal tatanan yang lebih mapan; e) Faktor intelegensi dan minat yaitu intelegensi merupakan modal untuk menalar, menganalisis dan menyimpulkan berdasar argumentasi yang matang, sehingga dapat menjadi dasar dalam melakukan penyesuaian diri. Di tambah faktor minat, pengaruhnya akan lebih nyata. Bila remaja telah memiliki minat terhadap sesuatu, maka proses penyesuaian biasanya cepat dan lancer; f) Faktor kepribadian yaitu pada prinsipnya tipe kepribadian ekstravet akan lebih lentur dan dinamis, sehingga lebih mudah melakukan penyesuaian diri dibanding tipe kepribadian intravet yang cenderung kaku dan statis. 2) Faktor-faktor eksternal, meliputi: a) 
Faktor keluarga, terutama pola asuh keluarga; b) Faktor kondisi sekolah; c) Faktor kelompok sebaya; d) Faktor prasangka social; e) Faktor hukum dan norma sosial.

Memang banyak hal yang mendorong dan membuat seseorang mampu untuk menyesuaikan diri dengan lingkungannya. Dorongan untuk mematuhi standar yang berlaku di lingkungan kampus tersebut diperkuat lagi dengan adanya hubungan timbal balik yang terjalin antara mahasiswa dengan lingkungan kampusnya. Hal tersebut sesuai dengan apa yang dikemukakan oleh Sofyan S. Willis bahwa penyesuaian diri di kampus meliputi: a) Penyesuaian diri terhadap guru atau dosen, b) Penyesuaian diri terhadap mata pelajaran, c) Penyesuaian diri terhadap teman sebaya dan d) Penyesuaian diri terhadap lingkungan sekolah/kampus (Willis, 1986).

Selanjutnya pengaruh dimensi-dimensi religious commitment terhadap penyesuaian diri juga menunjukkan pengaruh yang nyata terhadap penyesuaian diri mahasiswa. Pengaruh religious belief dengan penyesuaian diri mahasiswa di kampus IAIN Antasari Banjarmasin diperoleh angka sebesar 0.484 , berarti terdapat pengaruh yang positif antara religious belief dengan penyesuaian diri mahasiswa. Ini bermakna bahwa semakin tinggi atau meningkat religious belief yang dimiliki mahasiswa, maka semakin tinggi atau meningkat kemampuan penyesuaian diri mahasiswa di kampus IAIN Antasari Banjarmasin.

Mahasiswa IAIN Antasari Banjarmasin memiliki religious belief/ideologi sangat tinggi (93.2 persen). Ini berarti 93.2 persen mahasiswa memiliki memiliki keyakinan yang kuat terhadap agama Islam. Religous belief ini perlu dikembangkan pada diri mahasiswa karena dapat meningkatkan kemampuan penyesuaian diri mahasiswa di kampus IAIN Antasari Banjarmasin, karena religious belief merupakan determinan penting terhadap kemahiran seseorang dalam menyesuaikan diri dengan lingkungan.

Pengaruh religious practice dengan penyesuaian diri mahasiswa diperoleh angka sebesar 0.596, yang berarti terdapat pengaruh yang positif antara religious ritualistic dengan penyesuaian diri mahasiswa. Ini berarti bahwa semakin tinggi atau meningkat religious practice atau ritualistic yang dimiliki mahasiswa, maka semakin tinggi atau meningkat kemampuan penyesuaian diri mahasiswa. 
Hasil empirik dari penelitian ini menunjukkan bahwa mahasiswa IAIN Antasari Banjarmasin hanya 17.4 persen memiliki religious practice sangat tinggi. Ini berarti 17.4 persen mahasiswa rajin melaksanakan ajaran agama sesuai dengan prilaku-prilaku yang specifik yang menjadi bagian agama tersebut. Religous ritualistic/practice ini perlu dikembangkan pada diri mahasiswa karena dapat meningkatkan kemampuan penyesuaian diri mahasiswa.

Pengaruh religious feeling dengan penyesuaian diri mahasiswa diperoleh angka sebesar 0.667, nilai positif ini berarti bahwa semakin tinggi atau meningkat religious feeling yang dimiliki mahasiswa, maka semakin tinggi atau meningkat kemampuan penyesuaian diri mahasiswa di kampus IAIN Antasari Banjarmasin.

Mahasiswa yang memiliki religious feeling sangat tinggi 71.6 persen. Hal ini menggambarkan bahwa mahasiswa memiliki perasaan memiliki yang tinggi terhadap agama dan merasakan kelezatan beragama, dan merasakan pengalaman religius.

Adapun pengaruh religious knowledge dengan penyesuaian diri mahasiswa diperoleh angka 0.613, angka merupakan angka yang positif berarti terdapat pengaruh yang positif antara religious knowledge dengan penyesuaian diri mahasiswa. Ini berarti bahwa semakin tinggi atau meningkat religious knowledge yang dimiliki mahasiswa, maka semakin tinggi atau meningkat kemampuan penyesuaian diri mahasiswa. Hasil empirik dari penelitian ini menunjukkan bahwa 51.3 persen mahasiswa memiliki religious knowledge sangat tinggi. Ini berarti 51.3 persen mahasiswa memiliki informasi dan pengetahuan yang baik terhadap agama yang yakininya.

Kemudian pengaruh religious consequency atau religious effect terhadap penyesuaian diri mahasiswa diperoleh angka sebesar 0.689, berarti terdapat pengaruh yang positif antara religious effect dengan penyesuaian diri mahasiswa. Hasil empirik menunjukkan bahwa 53.4 persen mahasiswa memiliki religious effect sangat tinggi. Ini berarti 53.4 persen mahasiswa merasakan efek atau dampak dari agama yang dianutnya baik secara fisik maupun secara psikologis.

Dengan demikian masing-masing dimensi religious commitment baik religious belief, religious practice, religious feeling, religious knowledge dan religious effect memberikan mengaruh yang signifikan (nyata) terhadap penyesuaian diri mahasiswa di kampus IAIN Antasari. 
Apabila nilai keeratan hubungan pengaruh religious belief, religious practice/ritualistic, religious feeling/experience, religious knowledge, dan religious effect/ counsequence terhadap penyesuaian diri mahasiswa di kampus tersebut dikonfirmasikan dengan nilai interpretasi keeratan hubungan yang diajukan Sugiono (Sugiono, 2007), maka terlihat bahwa hubungan pengaruh dimensi religious belief dan religious practice/ritualistic, berada pada kriteria sedang atau moderat. Sedangkan dimensi religious feeling/experience, religious knowledge, dan religious effect/ counsequence berada pada kriteria kuat. Dari masing-masing dimensi religious commitment yang menunjukkan tingkat pengaruh yang kuat dengan penyesuaian diri, dimensi religious effect menunjukkan tingkat pengaruh yang lebih tinggi dari dimensi-dimensi yang lain, kemudian urutan pengaruh yang lebih tinggi selanjutnya adalah dimensi religious feeling, kemudian religious knowledge, selanjutnya religious practice, dan religious belief. Adanya pengaruh yang moderat dari dimensi religious belief dan religious practice/ritualistic, perlu mendapat perhatian dengan meningkatkan pengetahuan agama dan sekaligus mengamalkan ajaran agama mahasiswa, sehingga religious commitment mahasiswa menjadi semakin baik yang pada akhirnya dapat mengembangkan kemampuan penyesuaian diri mahasiswa, di samping faktorfaktor lain yang juga turut mendukung perkembangan tingkah laku penyesuaian diri mahasiswa.

\section{Kesimpulan}

Berdasarkan hasil penelitian yang telah diuraikan dapat disimpulkan bahwa kemampuan religious commitment dan kemampuan penyesuaian diri yang dimiliki mahasiswa IAIN Antasari adalah baik. Selanjutnya berdasarkan uji hipotesis penelitian terbukti bahwa terdapat pengaruh yang nyata (signifikan) religious commitment terhadap penyesuaian diri mahasiswa di kampus IAIN Antasari Banjarmasin. Semakin tinggi religious commitment yang dimiliki mahasiswa maka semakin tinggi pula kemampuan penyesuaian diri mahasiswa. Sehingga religious commitment perlu kembangkan di kampus IAIN Antasari agar penyesuaian diri mahasiswa menjadi lebih baik.

Masing-masing dimensi dari religious commitment (religious belief, practice, feeling, knowledge, effect) juga menunjukkan adanya pengaruh positif dan signifikan terhadap kemampuan 
penyesuaian diri mahasiswa di kampus IAIN Antasari. Artinya pertambahan tingkat pada masing-masing dimensi tersebut akan menambah tingkat kemampuan penyesuaian diri mahasiswa di kampus IAIN Antasari. Adapun keeratan hubungan masing-masing dimensi menunjukkan religous belief dan religous practise memiliki keeratan hubungan yang moderat (sedang) dengan kemampuan penyesuaian diri mahasiswa. Dimensi religious feeling, knowledge dan effect memiliki keeratan hubungan yang kuat dengan kemampuan penyesuaian diri mahasiswa.

Saran

Bagi kampus IAIN Antasari, perlu mengembangkan berbagai kegiatan yang dapat meningkatkan religious commitment mahasiswa baik menyangkut aspek religious belief, ritualistic/practice, feeling, knowledge maupun effect karena dengan meningkatnya religious commitment mahasiswa dapat meningkatkan kemampuan penyesuaian diri mahasiswa secara baik di lingkungan kampus.

Bagi pada peneliti selanjutnya dapat mengembangkan penelitian ini dengan mengkaji salah satu variabel dengan menghubungkannya dengan variabel lain di luar penelitian ini. Misalnya variabel kemampuan penyesuaian diri dikaitkan dengan variabel lain. Atau mengembangkan penelitian ini dengan metode yang lebih bervariasi.

\section{Kepustakaan}

Glock, C. Y. (1973). Faulkner (ed.). Religion's Influence in Contemporary Society: Readings in the Sociology of Religion (Book Review). Rural Sociology, 38(2), 250.

Glock, C. Y., \& Stark, R. W. (1970). American Piety: The Nature Religious commitment (Pattern of Religious Commitment). Barkeley California: University of California.

Fatimah, E. (2006). Psikologi Perkembangan (Perkembangan Peserta Didik). Bandung: Pustaka Setia. Kerlinger, F. N. (2004). Asas-asas Penelitian behavioral. Yogyakarta: UGM Press.

Jong, G. F. D., Faulkner, J. E., \& Warland, R. H. (1976). Dimensions of Religiosity Reconsidered: Evidence from a Cross-Cultural Study. Social Forces, 54(4), 866-889.

Agustiani, H. (2006). Psikologi Perkembangan: Pendekatan Ekologi Kaitannya dengan Konsep iri dan Penyesuaian Diri pada Remaja. Bandung: Refika Aditama.

Hassan, R. (2005). On Being Religious: Patterns of Religious commitment in Muslim Societies (Paper). Singapore: Institute of Defence and Strategic Studies.

Schneiders, A. A. (1960). Personal Adjustment and Mental Health. New York City: Holt Rinerhart and Winston.

Hariyadi, S. (1995). Perkembangan Peserta Didik. Perkembangan Peserta Didik: IKIP Semarang 
Press.

Sugiono. (2007). Statistika untuk Penelitian. Bandung: Alfabeta.

Willis, S. S. (1986). Problema Remaja dan Pemecahannya. Bandung: Angkasa. 